Article

\title{
Expression and Activity of COX-1 and COX-2 in Acanthamoeba sp.-Infected Lungs According to the Host Immunological Status
}

\author{
Natalia Łanocha-Arendarczyk ${ }^{1}$, Irena Baranowska-Bosiacka ${ }^{2}$, Karolina Kot ${ }^{1}$, \\ Izabela Gutowska ${ }^{3}$, Agnieszka Kolasa-Wołosiuk ${ }^{4}$, Dariusz Chlubek ${ }^{2}$ and \\ Danuta Kosik-Bogacka ${ }^{1, *}$ \\ 1 Department of Biology and Medical Parasitology, Pomeranian Medical University in Szczecin, \\ 70-204 Szczecin, Poland; nlanocha@pum.edu.pl (N.Ł.-A.); kotkarolina17@gmail.com (K.K.) \\ 2 Department of Biochemistry and Medical Chemistry, Pomeranian Medical University in Szczecin, \\ 70-204 Szczecin, Poland; ika@pum.edu.pl (I.B.-B.); dchlubek@pum.edu.pl (D.C.) \\ 3 Department of Biochemistry and Human Nutrition, Pomeranian Medical University in Szczecin, \\ 70-204 Szczecin, Poland; izagut@poczta.onet.pl \\ 4 Department of Histology and Embryology, Pomeranian Medical University in Szczecin, 70-204 Szczecin, \\ Poland; agnieszka.kolasa@pum.edu.pl \\ * Correspondence: kodan@pum.edu.pl; Tel.: +48-91-466-1672
}

Received: 30 November 2017; Accepted: 27 December 2017; Published: 2 January 2018

\begin{abstract}
Little is known about the pathomechanism of pulmonary infections caused by Acanthamoeba $\mathrm{sp}$. Therefore, the aim of this study was to determine whether Acanthamoeba sp. may affect the expression and activity of cyclooxygenase- 1 (COX-1) and cyclooxygenase-2 (COX-2), resulting in the altered levels of their main products, prostaglandins $\left(\mathrm{PGE}_{2}\right)$ and thromboxane $\mathrm{B}_{2}\left(\mathrm{TXB}_{2}\right)$, in lungs of immunocompetent or immunosuppressed hosts. Acanthamoeba sp. induced a strong expression of COX-1 and COX-2 proteins in the lungs of immunocompetent mice, which, however, did not result in significant differences in the expression of $\mathrm{PGE}_{2}$ and $\mathrm{TXB}_{2}$. Our immunohistochemical analysis showed that immunosuppression induced by glucocorticoids in Acanthamoeba sp.-infected mice caused a decrease in COX-1 and COX-2 (not at the beginning of infection) in lung tissue. These results suggest that similar to COX-2, COX-1 is an important mediator of the pathophysiology in experimental pulmonary acanthamoebiasis. We suggest that the signaling pathways important for Acanthamoeba sp. induction of lung infection might interact with each other and depend on the host immune status.
\end{abstract}

Keywords: Acanthamoeba sp.; lungs; cyclooxygenase 1 (COX-1); cyclooxygenase 2 (COX-2); prostaglandin $\mathrm{E}_{2}\left(\mathrm{PGE}_{2}\right)$; thromboxane $\mathrm{B}_{2}\left(\mathrm{TXB}_{2}\right)$

\section{Introduction}

Free-living amoeba of the genera Acanthamoeba can infect the central nervous system, causing granulomatous amebic encephalitis (GAE) in both immunocompetent and immunosuppressed patients [1]. They also cause Acanthamoeba keratitis (AK), cutaneous acanthamoebiasis (CA), and lung infection (Acanthamoeba pneumonia) [2,3]. Park et al. [4] found that Acanthamoeba sp. can induce airway inflammation via a protease allergen. Pneumonia caused by Acanthamoeba sp. has also been reported in a child with congenital immunodeficiency and in a lung transplant patient $[5,6]$.

The diagnosis of pulmonary infections with Acanthamoeba can be based on the identification of stages (trophozoites and/or cysts) in bronchoalveolar lavage samples and cultivations [7]. Our previous study was the first to isolate Acanthamoeba sp. in the bronchoaspirate of immunosuppressed patients with atypical symptoms of pneumonia [2]. In experimental animal models, 
Acanthamoeba sp. has been observed to cause damage to the pulmonary parenchyma, inflammatory infiltrate and destruction of the respiratory epithelium, blood vessels, bronchi and bronchioles $[7,8]$.

The intensity of inflammation, e.g., in lung tissues, depends on the functionality of the immune system. In pneumonia, the innate immunity of the lung tissue may be regulated by the increased expression of cytokines, chemokines and cyclooxygenase (COX) $[9,10]$. In this paper, we focus on COX, the key enzyme in the conversion of arachidonic acid to prostaglandin (PGE), the precursor of bioactive lipid mediators, including PGs, thromboxanes (TXs) and prostacyclin. Prostaglandin $\mathrm{E}_{2}\left(\mathrm{PGE}_{2}\right)$ is the most important prostaglandin which mediates the typical symptoms of inflammation: rubor, calor, tumor and dolor. It may act on neurons and contributes to the systemic responses to inflammation such as fever and fatigue [11,12]. PGE $_{2}$ also has a bronchodilatory effect and inhibits both early and late phase responses to allergens and other triggers of bronchoconstriction [13-15]. Thromboxanes are important mediators of inflammation. Thromboxane $\mathrm{B}_{2}\left(\mathrm{TXB}_{2}\right)$ is a metabolic product of thromboxane $A_{2}$, a potent bronchoconstrictor [16]. Increased $T X B_{2}$ levels have been reported in the airways of asthmatics following exposure to allergens [14,17].

Cyclooxygenase occurs in two isoforms, constitutive cyclooxygenase-1 (COX-1) and induced cyclooxygenase-2 (COX-2), which differ in their pattern of expression. In most tissues, COX-1 is involved in the maintenance of homeostasis, with increased expression in rheumatoid arthritis. The presence of COX-1 has been demonstrated in both the upper and lower respiratory tracts as well as in the pleura $[18,19]$. COX-2 participates in physiological and pathological processes, and its physiological presence has been identified. In the postnatal period, expression of COX-2 is low and limited to the bronchial epithelium and pulmonary alveoli $[19,20]$. COX-2 expression has been reported to be associated with inflammation or proliferative changes in the airway epithelium, including pneumonia and lung cancer [10]. Similar to COX-1, COX-2 plays an important role in allergic lung inflammation and asthma [9]. COX-2 has been shown to be induced by parasitic infections, but the mechanism is not clear [21]. In opportunistic parasitic infection, a strong correlation has been observed between COX-2 expression and Cryptosporidium sp. infection in the lungs and epithelial lining of the respiratory tract [22].

An immunoregulatory role for prostaglandins has been observed in Entamoeba histolytica and Leishmania amazonensis infections [23-25]. Leishmania donovani infections induce $\mathrm{PGE}_{2}$ generation within the host macrophages to aid in parasite survival [25]. $\mathrm{PGE}_{2}$ mediates immunosuppression that occurs in the acute phase of Chagas disease [26-28]. Anyona et al. [29] noted that the down regulation of $\mathrm{PGE}_{2}$ levels in Plasmodium falciparum infection correlated with increased clinical manifestation in brain Plasmodium infection, anemia and malaria during pregnancy. There is some evidence of a relationship between Acanthamoeba sp. infection and changes in $\mathrm{PGF}_{2}$ alpha depending on the pathogenicity of the amoeba strain. The pathogenic strains of Acanthamoeba castellanii produce more $\mathrm{PGF}_{2}$ alpha than non-pathogenic strains, but they do not differ markedly in $\mathrm{PGE}_{2}$ synthesis [30].

Understanding the mechanisms of acanthamoebiasis and how prostanoids modulate the immune response may help in limiting cellular damage, resulting in a development or change in pharmacological therapy. No studies to date have addressed the implications of the role of COX-1 and COX-2 enzymes and their metabolites in Acanthamoeba sp. lung infections in immunocompetent or immunosuppressed hosts. Thus, to clarify the role of prostanoids in lung acanthamoebiasis in relation to the host immune status, the purpose of this study was to determine whether Acanthamoeba sp. may affect the expression and activity of COX-1 and COX-2, resulting in altered levels of their main products, $\mathrm{PGE}_{2}$ and $\mathrm{TXB}_{2}$.

\section{Results}

\subsection{Body Weight, Lung Weight and Lung Weight Ratio}

The body and lung weights of the mice in the control and infected groups are shown in Table 1, lung weight ratio is presented in Figure 1. We observed lower total body and lung weights in the 
immunocompetent Acanthamoeba sp.-infected mice compared to the immunocompetent control mice, and significant differences in total lung mass between mice from group A and the AS (Table 1). Statistically significant differences of total body mass were found between groups $\mathrm{A}$ and $\mathrm{C}$ and groups $\mathrm{A}$ and AS at 16 days post Acanthamoeba sp. infection (dpi). There were no statistically significant differences in lung weight at 8, 16 and $24 \mathrm{dpi}$ in all groups. In immunocompetent Acanthamoeba sp.-infected mice, lung weight ratio was the highest at $16 \mathrm{dpi}$ and in immunosuppressed infected mice at 24 dpi (Figure 1). Strain AM 22 showed pneumophilic properties; numerous amoebae trophozoites were observed $12 \mathrm{~h}$ after mice inoculation near the lung fragments from Acanthamoeba sp.-infected immunocompetent and immunosuppressed mice.

Table 1. Body and lungs weights of male mice (in $\mathrm{g}$ ) in control and infected groups after 8, 16 and 24 days post Acanthamoeba sp. infection (dpi).

\begin{tabular}{|c|c|c|c|c|c|c|c|}
\hline Parameter & $\mathrm{n} / \mathrm{g}$ & Group & $\mathrm{C}$ & CS & A & AS & P (K-W Test) \\
\hline \multicolumn{8}{|c|}{ Body mass } \\
\hline & $\mathrm{n}$ & & 18 & 18 & 30 & 30 & \\
\hline Total & $\mathrm{g}$ & $\begin{array}{l}\mathrm{AM} \pm \mathrm{SD} \\
\text { Median } \\
\text { Range }\end{array}$ & $\begin{array}{c}26.30 \pm 1.88 \text { * } \\
26.59 \\
21.34-30.13\end{array}$ & $\begin{array}{c}29.28 \pm 1.58 \\
29.30 \\
27.20-32.80\end{array}$ & $\begin{array}{c}24.57 \pm 4.19 *, \# \\
25.47 \\
13.41-29.50\end{array}$ & $\begin{array}{c}28.30 \pm 3.29 \# \\
29.30 \\
20.04-33.01\end{array}$ & 0.0001 \\
\hline 8 dpi & $\mathrm{g}$ & $\begin{array}{l}\mathrm{AM} \pm \mathrm{SD} \\
\text { Median } \\
\text { Range }\end{array}$ & $\begin{array}{c}25.47 \pm 2.92 \\
26.06 \\
21.34-30.13\end{array}$ & $\begin{array}{c}28.18 \pm 0.93 \\
27.70 \\
27.30-29.05\end{array}$ & $\begin{array}{c}24.15 \pm 4.16 \\
25.16 \\
13.41-27.26\end{array}$ & $\begin{array}{c}29.78 \pm 1.25 \\
29.45 \\
28.41-32.40\end{array}$ & 0.41 \\
\hline 16 dpi & $\mathrm{g}$ & $\begin{array}{l}\mathrm{AM} \pm \mathrm{SD} \\
\text { Median } \\
\text { Range }\end{array}$ & $\begin{array}{c}26.55 \pm 0.65 * \\
26.62 \\
25.59-27.55\end{array}$ & $\begin{array}{c}29.7 \pm 1.51 \\
29.70 \\
27.2-31.6\end{array}$ & $\begin{array}{c}21.65 \pm 3.91 * \# \\
22.04 \\
15.58-26.91\end{array}$ & $\begin{array}{c}28.5 \pm 4.45^{\#} \\
29.05 \\
20.04-33.01\end{array}$ & 0.001 \\
\hline \multicolumn{8}{|c|}{ Lung mass } \\
\hline & $\mathrm{n}$ & & 18 & 18 & 30 & 30 & \\
\hline Total & $\mathrm{g}$ & $\begin{array}{l}\mathrm{AM} \pm \mathrm{SD} \\
\text { Median } \\
\text { Range }\end{array}$ & $\begin{array}{c}0.19 \pm 0.03 * \\
0.19 \\
0.15-0.23\end{array}$ & $\begin{array}{c}0.22 \pm 0.03 \\
0.20 \\
0.10-0.30\end{array}$ & $\begin{array}{c}0.21 \pm 0.18 * \\
0.17 \\
0.12-1.10\end{array}$ & $\begin{array}{c}0.20 \pm 0.04 \\
0.20 \\
0.10-0.30\end{array}$ & 0.001 \\
\hline & $\mathrm{n}$ & & 6 & 6 & 10 & 10 & \\
\hline $8 \mathrm{dpi}$ & $\mathrm{g}$ & $\begin{array}{l}\mathrm{AM} \pm \mathrm{SD} \\
\text { Median } \\
\text { Range }\end{array}$ & $\begin{array}{c}0.20 \pm 0.04 \\
0.21 \\
0.15-0.26\end{array}$ & $\begin{array}{c}0.22 \pm 0.04 \\
0.20 \\
0.20-0.30\end{array}$ & $\begin{array}{c}0.18 \pm 0.05 \\
0.17 \\
0.12-0.28\end{array}$ & $\begin{array}{c}0.21 \pm 0.03 \\
0.20 \\
0.20-0.30\end{array}$ & 0.25 \\
\hline
\end{tabular}

C, immunocompetent uninfected control group mice; CS, immunosuppressed uninfected mice; A, immunocompetent Acanthamoeba sp.-infected mice; AS, immunosuppressed Acanthamoeba sp.-infected mice; AM arithmetic mean; SD standard deviation; P level of significance; K-W test Kruskal-Wallis test; ${ }^{*} p \leq 0.05$ for the significance of difference vs. control (Mann-Whitney $U$ test); ${ }^{\#} p \leq 0.05$ for the significance of difference A vs. AS (Mann-Whitney $U$ test). 


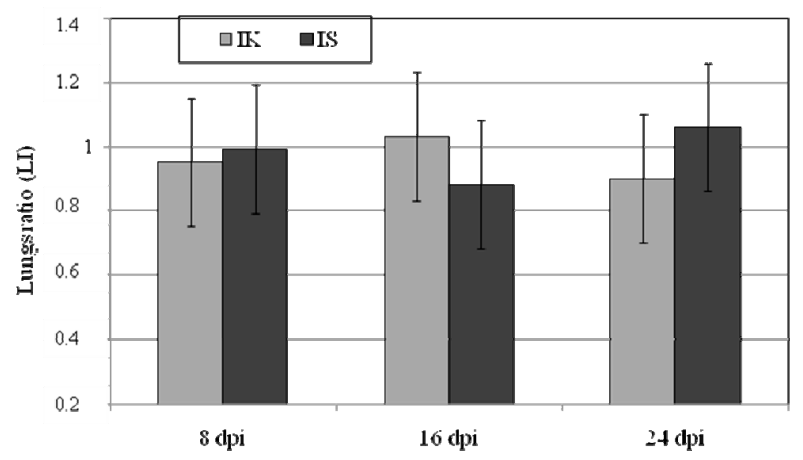

Figure 1. The relative weight ratio of lungs (LI) in relation to control groups: immunocompetent (IK) and immunosuppressed (IS) in various $(8,16,24)$ days post Acanthamoeba sp. infection (dpi). Data represent the mean \pm standard deviation (SD).

\subsection{Acanthamoeba sp. COX-1 Expression in Lungs During Infection}

We observed statistically significant differences in lung COX-1 protein expression in Acanthamoeba sp.-infected immunocompetent mice vs. the immunocompetent control group (Figure 2). The highest expression of COX-1 protein in the lungs was found in Acanthamoeba sp.-infected immunocompetent mice at $24 \mathrm{dpi}$, significantly higher than in the control group (by $44 \%, p=0.025$ ). A significant increase in expression of the enzyme compared with control was also observed in group A at $16 \mathrm{dpi}(33 \%$, $p=0.022)$ and $8 \mathrm{dpi}(12 \%, p=0.042)$ vs. control group. Expression of the enzyme in group A was also significantly higher than in the Acanthamoeba sp.-infected immunosuppressed mice at 8 dpi (by $50 \%$, $p=0.004$ ), $16 \mathrm{dpi}$ (by 52\%, $p=0.002$ ), and $24 \mathrm{dpi}$ (by $64 \%, p=0.002$ ), and significantly positively correlated with the time of infection $(\mathrm{rs}=+0.49)$.

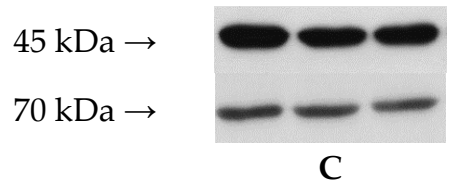

C

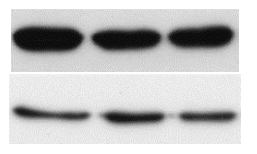

CS

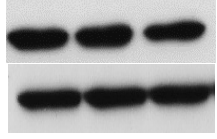

A

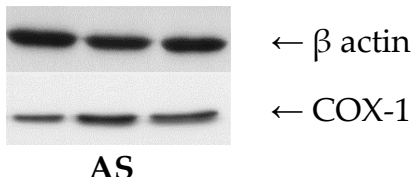

AS

(a)

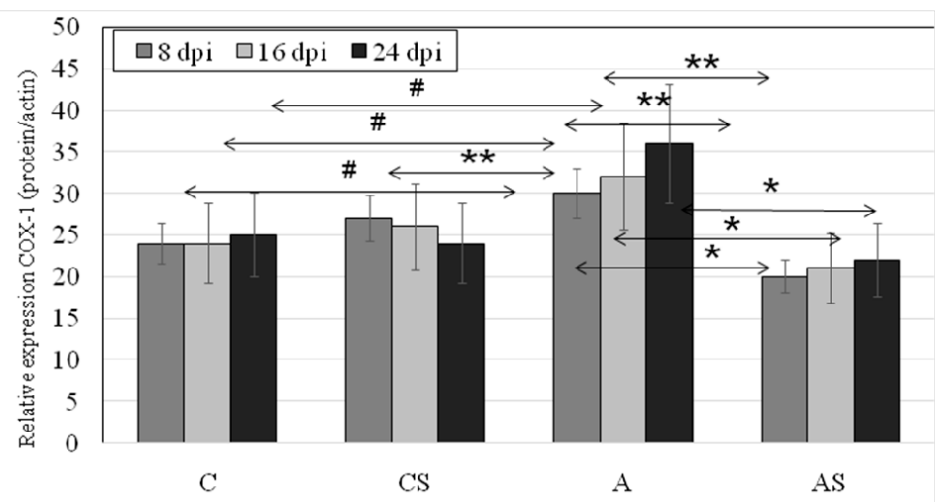

(b)

Figure 2. The effect of Acanthamoeba sp. infection on the expression of cyclooxygenase 1 (COX-1) in mouse lungs. Cyclooxygenase 1 was determined using Western blot analysis. Representative Western blots (a) and densitometric analysis of COX-1 protein normalized to $\beta$-actin $(\mathbf{b})$ in mouse lungs were shown. Data represent the means \pm standard deviation (SD) for six in dependent experiments. $\# p<0.05$ vs .control group; $* p<0.05$ infected immunocompetent mice vs. infected immunosuppressed mice, ${ }^{* *} p<0.05$ vs. infected group, using a Mann-Whitney $U$ test. 


\subsection{Acanthamoeba sp. COX-2 Expression in Lungs During Infection}

In the Acanthamoeba sp.-infected immunocompetent mice the expression of COX-2 protein was significantly higher than in the control group at 8 dpi (by 50\%, $p=0.002$ ), 16 dpi (by $75 \%, p=0.001$ ) and $24 \mathrm{dpi}$ (by $80 \%, p=0.003$ ). There was an upward trend in the expression of the enzyme in relation to the duration of infection, but the observed differences were not statistically significant. COX-2 expression was different in Acanthamoeba sp.-infected immunocompetent mice and was significantly higher than in Acanthamoeba sp.-infected immunosuppressed mice (Figure 3). The highest expression of the enzyme was observed in A group at $24 \mathrm{dpi}, 52 \%$ higher $(p=0.003)$ vs. AS group. Also at $8 \mathrm{dpi}$ COX-2 expression was 50\% higher ( $p=0.001$ ) and at 16 dpi was significantly higher (by $59 \%, p=0.004$ ) compared to Acanthamoeba sp.-infected immunosuppressed mice.

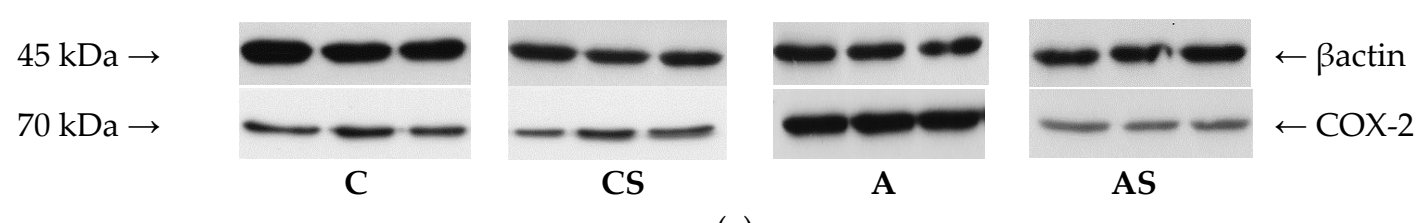

(a)

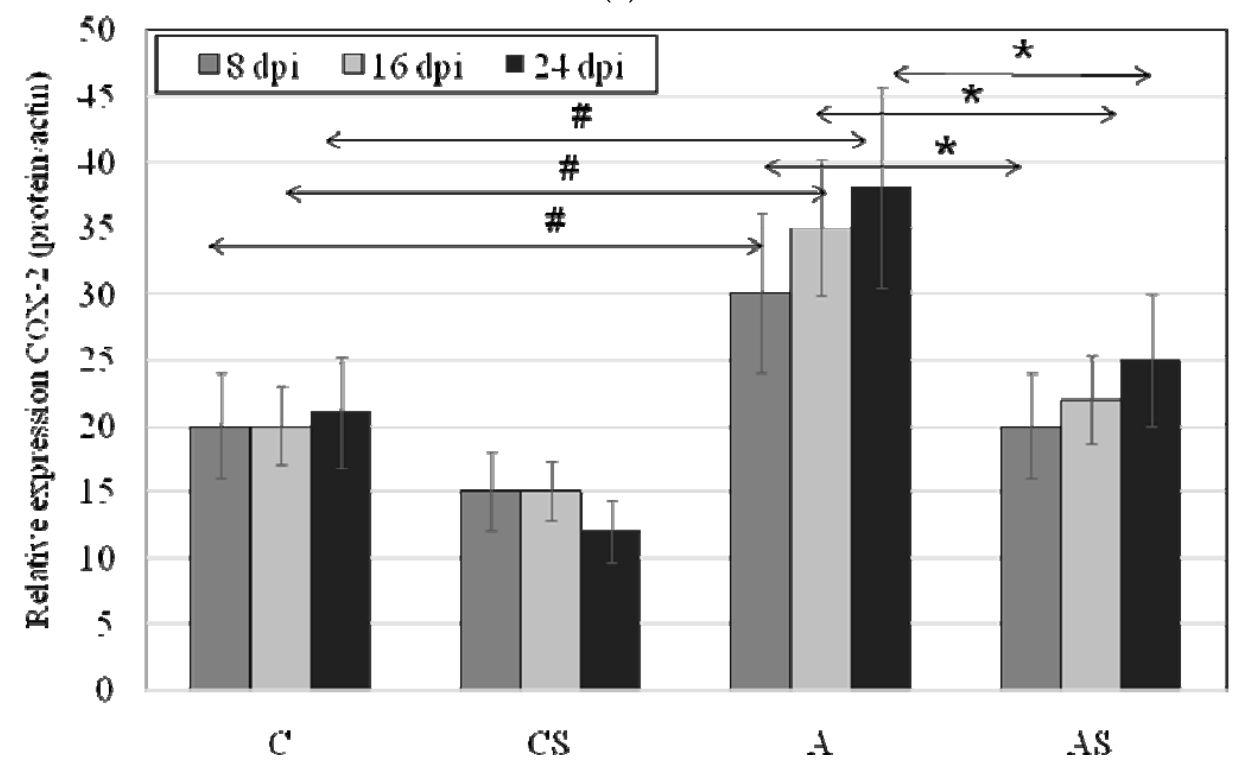

(b)

Figure 3. The effect of Acanthamoeba sp. infection on the expression of cyclooxygenase 2 (COX-2) in mouse lungs. Cyclooxygenase 2 was determined using Western blot analysis. Representative Western blots (a) and densitometric analysis of COX-2 protein normalized to $\beta$-actin (b) in mouse lungs were shown. Data represent the means \pm standard deviation (SD) for six independent experiments. $\# p<0.05$ vs. control group; ${ }^{*} p<0.05$ infected immunocompetent mice vs. infected immunosuppressed mice, using a Mann-Whitney $U$ test.

\section{4. $P G E_{2}$ in Lungs During Acanthamoeba sp. Infection}

We did not observe statistically significant differences in lung $\mathrm{PGE}_{2}$ concentration between the immunocompetent control group and Acanthamoeba sp.-infected immunocompetent mice (Figure 4). Lung PGE 2 was the highest at $24 \mathrm{dpi}$ in Acanthamoeba sp.-infected animals and almost 19\% higher than in the uninfected control mice. In A group we observed an increase $\mathrm{PGE}_{2}$ concentration progressing with the duration of infection, but it was not statistically significant. There were also no statistically differences in lung $\mathrm{PGE}_{2}$ concentrations between AS and CS groups. We observed higher levels of lung $\mathrm{PGE}_{2}$ in mice from A group in comparison to mice from AS group at $8 \mathrm{dpi}(p=0.04)$. 


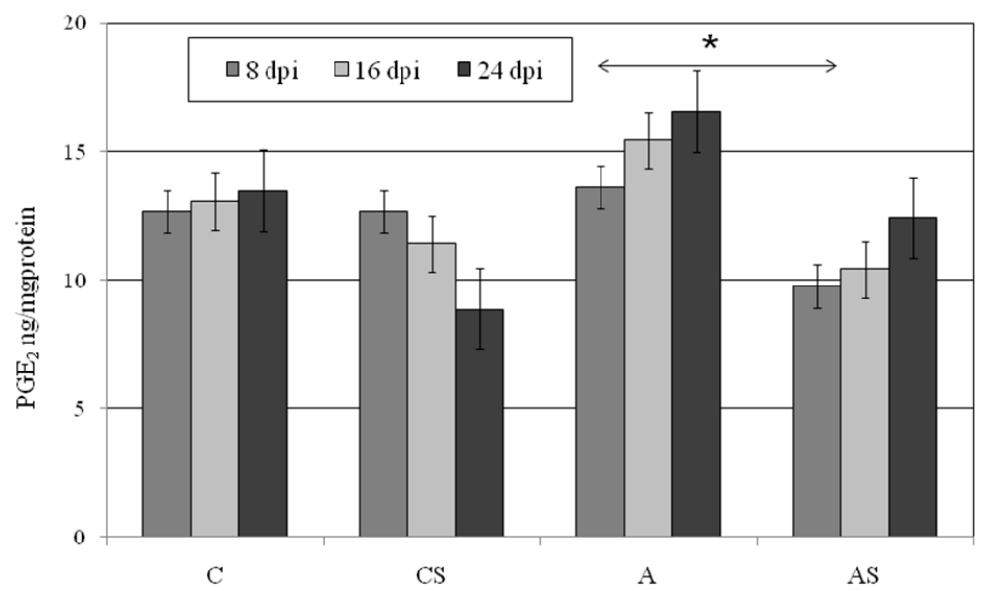

Figure 4. Changes in prostaglandin $\mathrm{E}_{2}\left(\mathrm{PGE}_{2}\right)$ levels in the lungs of Acanthamoeba sp.-infected mice depending on the host immune status $(\mathrm{C}$, immunocompetent uninfected control group mice; $\mathrm{CS}$, immunosuppressed uninfected mice; A, immunocompetent Acanthamoeba sp.-infected mice; AS, immunosuppressed Acanthamoeba sp.-infected mice; Data represent the mean \pm standard deviation (SD) for six in dependent experiments * $p \leq 0.05$ for the significance of difference A vs. AS (Mann-Whitney test; dpi days post infection).

\section{5. $T X B_{2}$ in Lungs during Acanthamoeba sp. Infection}

In the lungs of Acanthamoeba sp.-infected immunocompetent mice $\mathrm{TXB}_{2}$ at 16 and 24 dpi was higher than in control immunocompetent group at the same times, but not statistically significantly. In immunosuppressed animals: $\mathrm{AS}$ and $\mathrm{CS}$ groups lung $\mathrm{TXB}_{2}$ was the highest at 16 and $8 \mathrm{dpi}$, respectively. In the CS group, $\mathrm{TXB}_{2}$ could be arranged in the following descending order: $8>24>16 \mathrm{dpi}$, and in the AS group a reverse dependence was observed (16 $>24>8$ dpi), although these differences were statistically significant (Figure 5). In the lung of Acanthamoeba sp.-infected immunocompetent mice $\mathrm{TXB}_{2}$ was statistically significantly higher at $8 \mathrm{dpi}$ than in infected immunosuppressed animals $(p=0.03)$.

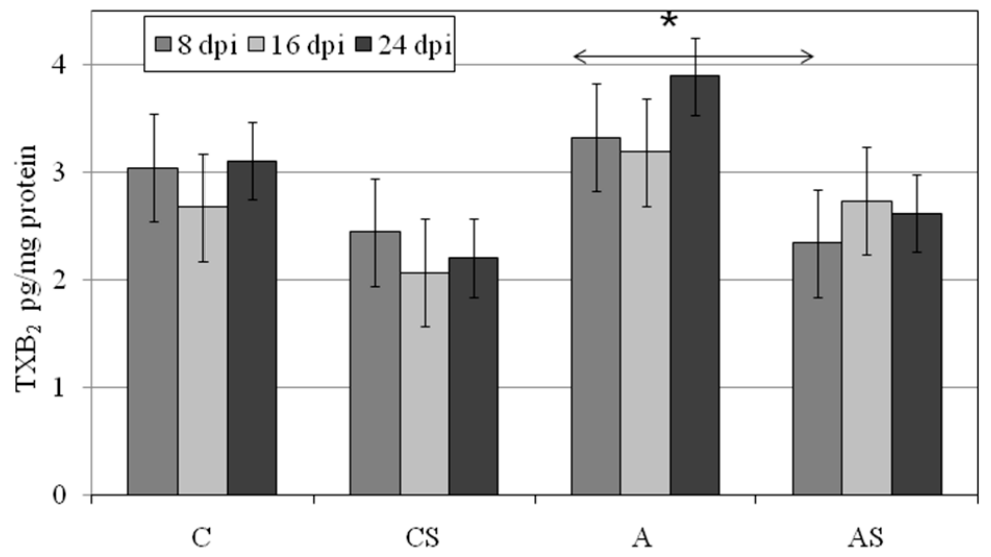

Figure 5. Changes in the levels of thromboxane $\mathrm{B}_{2}\left(\mathrm{TXB}_{2}\right)$ in the lungs of Acanthamoeba sp.-infected mice depending on the host immune status $(C$, immunocompetent uninfected control group mice; CS, immunosuppressed uninfected mice; A, immunocompetent Acanthamoeba sp.-infected mice; AS, immunosuppressed Acanthamoeba sp.-infected mice; dpi days post infection); Data represent the \pm standard deviation (SD) for six in dependent experiments * $p \leq 0.05$ for the significance of difference A vs. AS (Mann-Whitney $U$ test). 


\subsection{Immunohistochemistry}

The results of the immunohistochemical reactions showed that in Acanthamoeba-infected immunosuppressed mice during infection, the lungs exhibited changes in COX-1 (Figure 6G-L, respectively) and COX-2 (Figure 7G-L, respectively) expression in comparison to the control group (Figures 6 and 7A-C) and the uninfected immunosuppressed mice (Figures 6 and 7D-F).

\section{COX-1}

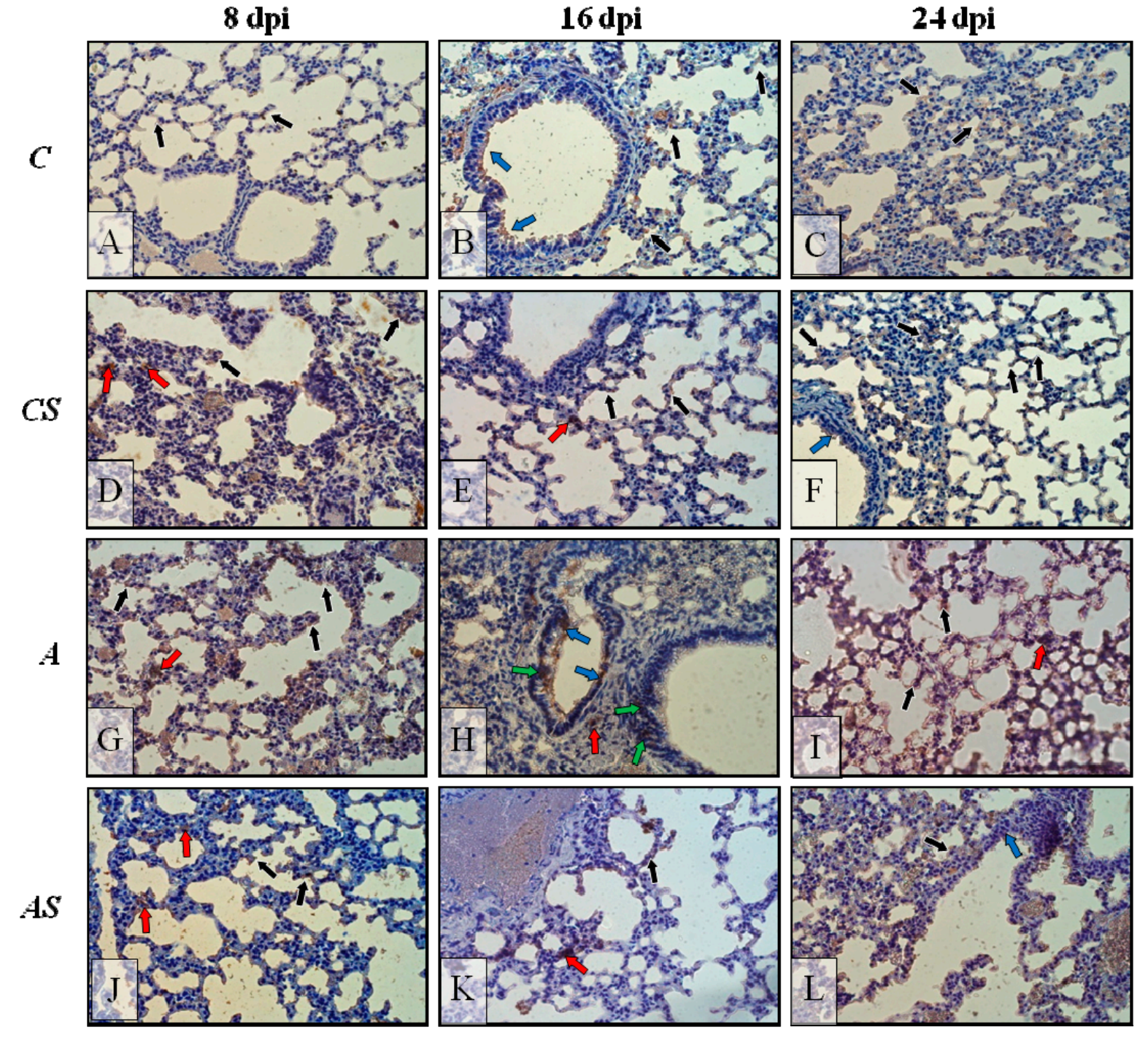

Figure 6. Representative microphotography showing immunoexpression (brown color) of COX-1 in mice lungs from control group (A-C), control drug treated group: CS (D-F), infected by Acanthamoeba sp. (G-I) and treated by drug during infection groups (J-L) in 8, 16 and 24 days post infection (dpi). The examples of immunopositive cells: epithelial cells of bronchioles, blue arrows; pneumocytes, black arrows; stromal cells, stromal cells of lung parenchyma-red arrows, intraepithelial lymphocytes-green arrows $\times 40$. (C, immunocompetent uninfected control group mice; CS, immunosuppressed uninfected mice; A, immunocompetent Acanthamoeba sp.-infected mice; AS, immunosuppressed Acanthamoeba sp.-infected mice; dpi, days post infection). 


\section{COX-2}

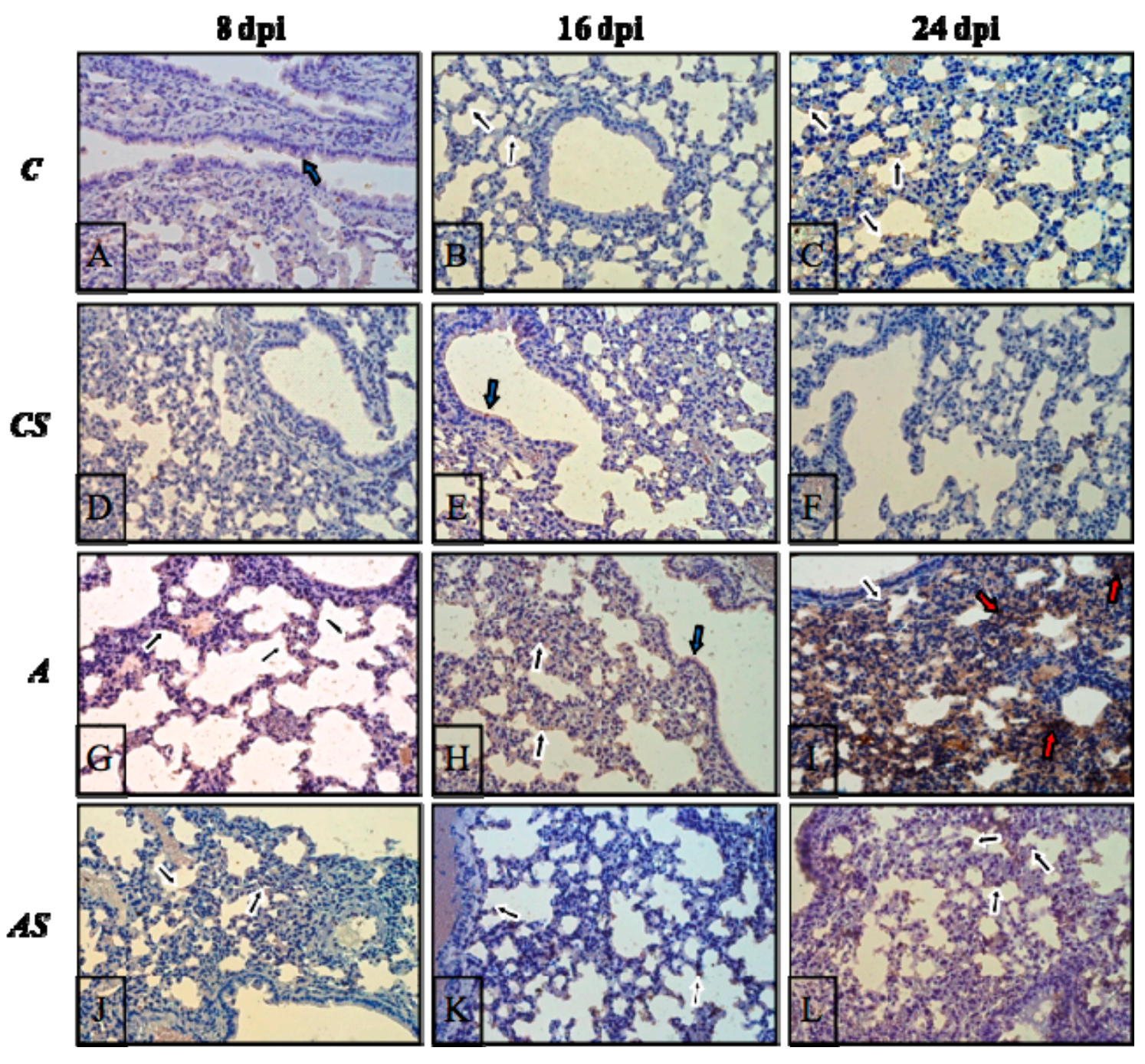

Figure 7. Representative microphotography showing immunoexpression (brown color) of COX-2 in mice lungs from control group (A-C), control drug treated group (D-F), infected by Acanthamoeba sp. (G-I) and treated by drug during infection groups (J-L) in 8, 16 and 24 days post infection (dpi). The examples of immunopositive cells: epithelial cells of bronchioles—blue arrows; pneumocytes—black arrows; stromal cells of lung parenchyma - red arrows. Objective magnification: $\times 40$. (C, immunocompetent uninfected control group mice; CS, immunosuppressed uninfected mice; A, immunocompetent Acanthamoeba sp.-infected mice; AS, immunosuppressed Acanthamoeba sp.-infected mice; dpi, days post infection).

In control mice lungs (Figure 6A-C), immunoexpression of COX-1 was low, almost at the same level regardless of the day of the infection $(8,16$ and 24$)$, with the enzyme visible mainly in pneumocytes and bronchial epithelial cells (black and blue arrows, respectively). After immunosuppression of the control animals, immunoexpression of COX-1 appears to be slightly higher (Figure 6D-F) and situated mostly in pneumocyte cytoplasm (black arrows), also in the apical region of epithelial cells bronchioles (but at a very low intensity; blue arrows) and sporadically in interstitial cells (red arrows). After Acanthamoeba sp. infection of immunocompetent hosts the level of COX-1 (Figure 6G-I) increased and intensified during the days following infection; COX-1-positive cells were pneumocytes (black arrows), bronchial epithelial cells (blue arrows), parenchyma cells (red arrows) and also intraepithelial lymphocytes localized in lining epithelium of bronchioles (green arrows). In immunosuppressed 
Acanthamoeba sp.-infected mice a decrease in COX-1 detection was observed (Figure 6J-L) in comparison to immunocompetent Acanthamoeba sp.-infected mice (Figure 6G-I) and was about the same level as in control groups (Figure 6A-F), but still at $24 \mathrm{dpi}$ immunoreactivity was higher than in the previous days of infection in this group (AS). Extinction/blanking of immunoreactivity mainly concerned bronchial epithelial and parenchyma cells (but a few immunopositive cells were visible; red arrows), pneumocytes were constantly showing COX-1 presence, but at a lower level.

In both uninfected groups (C, CS), the immunoexpression of COX-2 was very low at almost imperceptible levels (Figure 7A-F). Among the COX-2-positive cells were pneumocytes and epithelial cells (their apical part/cilia) of bronchioles (black and blue arrows). Decisive elevations in COX-2 level were observed in the lungs of the infected groups of mice (Figure 7G-I), wherethe highest expression of this isoform of cyclooxygenase was noted at $24 \mathrm{dpi}$ (Figure 7I); where besides pneumocytes (black arrows) or poorly positive bronchial epithelial cells (blue arrows), strong immunopositive levels were also noted in parenchyma cells (red arrows). The drug treatment resulted in a decrease of immunoreactivity of lung tissue (especially at $8 \mathrm{dpi}$ ) (Figure 7J), after that, it started to increase again (Figure $7 \mathrm{~K}, \mathrm{~L}$ ), but nevertheless, was at a lower level than in the infected immunocompetent animals (Figure 7G-I); among the mice of group (AS), the presence of COX-2 was noted most of all in the epithelial cells of alveoli (black arrows).

\section{Discussion}

Pulmonary epithelial cells play an active role in inflammation by producing cytokines and eicosanoids, which modulate the inflammatory and immunological host responses [19,31,32]. Little is known about the expression and activity of inflammatory enzymes COX-1 and COX-2 and their products in lungs infected by parasites, including free-living amoeba.

This study demonstrated that Acanthamoeba sp. strain (AM 22) isolated from the airways of a patient with AML and atypical pneumonia symptoms in our previous research was pneumophilic in both immunocompetent and immunosuppressed mice [2]. AM 22 significantly reduced total body mass in both immunocompetent and immunosuppressed hosts at $16 \mathrm{dpi}$. A reduction in body weight in immunocompetent amoeba-infected mice was not surprising, as confirmed in other studies including experimentally inducted cerebral malaria, blastocystosis and opportunistic Cryptosporidium sp. infection [33-35]. Moreover, infection with Acanthamoeba sp. did not affect lung weight in immunocompetent hosts and immunological host status did not significantly alter the weight ratio of lungs during the infection. An increase in lung weight is due primarily to the influx of inflammatory cells, as suggested by Wilson et al. [36].

For the first time, we observed that Acanthamoeba sp. induced a strong expression of COX-1 and COX-2 proteins in the lungs of immunocompetent hosts throughout infection. Increased COX-1 expression could be expected as it is constitutively expressed in most cells and tissues, and also involved in inflammatory processes, including lung inflammation [37]. Some researchers suggest that Acanthamoeba sp. elicits allergic airway symptoms in mice, so it is probable that this parasite may be one of the triggers of human airway allergic inflammation [4]. COX-1 plays a critical role in regulating airway function and airway inflammation following an allergic stimulus, but in some cases, such as lung tumors, the development of inflammation may result in increased expression of COX-1 gene and its protein expression $[37,38]$. We observed that COX-1 expression in the lungs from immunocompetent Acanthamoeba sp.-infected mice correlated with the infection time and that the concentrations of $\mathrm{PGE}_{2}$ and $\mathrm{TXB}_{2}$ in the lungs increased (but not significantly) over the following days of infection.

COX-2 has complex and poorly understood roles in anti-pathogen immunity [39]. The induction of COX-2 expression in lung tissues may be related to the direct regulatory function of pulmonary epithelial cells via cytokines released from alveolar macrophages on specific epithelial cells receptors, e.g., IL- $\beta$, a potent pro-inflammatory cytokine that is crucial for host-defense response [40]. In pulmonary cryptosporidiosis and in virus lung invasions, stimulation of COX-2 production is 
dependent on nuclear transcription factor (NF- $\mathrm{kB}$ ), which plays a role in immune and inflammatory processes [22,41,42]. Probably, Acanthamoeba sp. in the lung might cause marked upregulation of $\mathrm{NF}-\mathrm{kB}$, enhanced binding of NF- $\mathrm{KB}$ to COX-2 promoter, and COX-2 mRNA expression, then COX-2 protein production [22,37]. It is possible that Acanthamoeba sp. in the lungs, similar to other pulmonary pathogens, stimulates the expression of a number of proinflammatory gene products, including COX-2 and inducible nitric oxide synthase (iNOS) [22,42]. It has also been observed that COX-2 is regulated by Toll-like receptor 4 (TLR-4) in intestinal cells, and that TLR-4-mediated signaling is responsible for mucosal COX-2 expression and $\mathrm{PGE}_{2}$ synthesis in the setting of intestinal inflammation $[43,44]$. The dependence between COX enzymes and TLR-4 in lung tissues during parasite infection is not clear, albeit Derda et al. [45] found an increased level of expression of TLR2 as well as TLR4 mRNA in lungs during Acanthamoeba infection. Moreover, as was suggested by Kosik-Bogacka et al. [21] the increased COX expression and activity in the rat colon and jejunum in intestinal Hymenolepis diminuta infection is probably caused by increased levels of free radicals and a weakening of the host's antioxidant defense induced by the presence of the parasite [21]. In another study, the expression of COX-2 and production of $\mathrm{PGE}_{2}$ increased in response to acute respiratory infection with a variety of bacterial organisms and viruses [10]. Szymańsky et al. [10] observed that Streptococcus pneumonia, responsible for lungs bacterial invasions, was capable of inducing a strong expression of COX-2 whereas COX-1 was constitutively expressed and remained unaffected in the infected lung. Peres-Buzalaf et al. [46], in experimental bacterial pulmonary tuberculosis, observed $\sim 13$-times higher $\mathrm{PGE}_{2}$ concentration in the lung at 30 dpi compared to the control group. In contrast, Chen et al. [47] suggested that $\mathrm{PGE}_{2}$ is necessary to control Mycobacterium tuberculosis during the early stage of invasion. It is suggested that the secretion of this prostaglandin is an element of the feedback loop in the regulation of the immune system [48]. An increase in $\mathrm{PGE}_{2}$ suppresses immunity by blocking the activity of the immune system and inhibitsfurther synthesis of $\mathrm{PGE}_{2}$ [49]. Vancheri et al. [50] showed that pulmonary $\mathrm{PGE}_{2}$ has a role in limitingthe inflammatory response and tissue repair in contrast to its counterparts in other organs.

A chronic administration of specific COX-1 and COX-2 inhibitors or decreased expression of these enzymes can produce unexpected results. Classic non-steroidal anti-inflammatory drugs (NSAIDs) block prostaglandin synthesis by inhibiting both COX-1 and COX-2 enzymatic activities [51]. Moreover, glucocorticoids strongly suppress the expression of COX-2 induced by inflammatory stimuli [52]. Corticosteroids may modulate COX-2 expression by indirectly reducing IL-4 and IL-13, in contrast to TNF in the asthmatic airway which may induce COX-2 [16]. In this study immunohistochemical reactions showed that the immunosuppression induced by methylprednisolone, a synthetic glucocorticoid with a potent and long-acting anti-inflammatory, antiallergic and immunosuppressive action in Acanthamoeba sp.-infected mice caused a decreased in COX-1 detection and decrease in COX-2 immunoreactivity in the lung tissue (especially at the beginning of the infection), but not at 16 dpi and 24 dpi. Hideko Tatakihara et al. [53] in Trypanosoma cruzi infection showed that aspirin inhibited COX-1 more than COX-2 and the inhibition was irreversible. Reduced expression of COX-1, together with increased COX-2 expression, was found in the lungs of endotoxin lipopolysaccharide (LPS)-treated rats [54,55].

In this study, strong expression of COX-1 and COX-2 proteins in the lungs of immunocompetent hosts induced by the parasite did not result in a significant increase in their products, $\mathrm{PGE}_{2}$ and $\mathrm{TXB}_{2}$. Inflammation induced by the parasite may have initiated the immune response consisting of the inhibition of the enzyme by its product. The activity of COXs depends on many factors, including those that participate in the initiation and regulation of inflammation, i.e., MAP kinases, such as ERK $1 / 2$, JNK and p38 [56]. $\mathrm{PGE}_{2}$ and $\mathrm{TXB}_{2}$ produced in cells are released into the extracellular space directly via diffusion or through special membrane transporters-MRP ${ }_{4}$. The released prostaglandin $\mathrm{E}_{2}$ influences cells via membrane receptors $\mathrm{EP}_{1}-\mathrm{EP}_{4}$ [57], while thromboxane $\mathrm{B}_{2}$ via TP receptors [58]; all of these receptors belong to the G-protein-linked receptor superfamily [57]. Depending on the type of the stimulated receptor, cells experience a change in the levels of intracellular cAMP, calcium ions 
$\left(\mathrm{Ca}^{2+}\right)$ or change in the activity of phosphoinositide 3-kinase $[57,58]$, which in turn may regulate the activity of COXs and inhibit or activate inflammation.

\section{Materials and Methods}

\subsection{Acanthamoeba sp. Isolate and Cultivation}

The AM 22 strain was isolated from the bronchoaspirate of a 53-year-old man with an acute septic shock. Patient was in acute myeloid leukemia (AML), and atypical pneumonia was diagnosed [2]. The amoebas were grown on agar plates (NN Agar) covered with a suspension of deactivated bacteria Escherichia coli (deactivated at $70{ }^{\circ} \mathrm{C}$ for $1 \mathrm{~h}$ ) and incubated at $37^{\circ} \mathrm{C}$ for $72 \mathrm{~h}$ according to standard methods [59].

\subsection{Animals and Ethics Statement}

The study was conducted on 96 male Balb/c mice obtained from a licensed breeder-the Centre of Experimental Medicine, Medical University in Bialystok, Poland. Animals were about 6-10 weeks old at the beginning of the experiment and their mean weight was $23 \mathrm{~g}$. The mice had genetic and health certificates issued by a veterinarian. This study was approved by the Local Ethics Committee for Experiments on Animals in Szczecin (No. 29/2015, dated 22 June 2015) and Poznań (No. 64/2016 dated 9 September 2016). All animal experiments were conducted and handled in strict accordance with good animal practice within the recommendations in the Guide for the Care and Use of Laboratory Animals. Animals were subject to a 10-min procedure of daily manual handling consisting of keeping the mouse in one hand. Animals were housed in groups of 5 mice per cage on a $12 \mathrm{~h}$ light/dark cycle (controlled by automatic timers) in the Animal Facility of the Pomeranian Medical University in Szczecin, and were fed Labofeed H (Morawski, Kcynia, PL0410004p, Poland) and water ad libitum from a stoppered-bottle with a nose-activated nozzle. The room humidity was approximately $56 \%$ and air temperature $22 \pm 1{ }^{\circ} \mathrm{C}$. To prevent bacterial/viral infections, the cages, feed, water, and bedding were sterilized and changed daily.

The mice were divided into 4 groups:

- immunocompetent control group $(\mathrm{C}, n=18)$ untreated mice.

- immunocompetent $(\mathrm{A}, n=30)$ Acanthamoeba sp.-infected mice.

- $\quad$ immunosuppressed(AS, $n=30)$ Acanthamoeba sp.-infected mice.

- $\quad$ immunosuppressed(CS, $n=18)$ uninfected mice.

\subsection{Immunosuppression}

The Balb/c mice were immunosuppressed by administering $0.22 \mathrm{mg}(10 \mathrm{mg} / \mathrm{kg})$ methylprednisolone sodium succinate (MPS, Solu-Medrol, Pfizer, Puurs, Belgium, Europe MA EEIG) in $0.1 \mathrm{~mL}$ of $0.9 \%$ saline intraperitoneally (i.p.) at $-4,-3,-2,-1$ and 0 days before inoculation with the amoeba. The drug solution was prepared immediately prior to its administration at a dosage based on literature data [60]. Such an algorithm allowed the development of an experimental model similar to that of immunosuppressed patients. MPS is administered, among others, to patients treated for acute rejection episodes.

\subsection{Intranasal Inoculation and Pathogenic Test}

The mice (groups A and AS) were inoculated intra-nasally with $3 \mu \mathrm{L}$ of suspension containing 10-20 thousand amoebae. Control animals (groups $C$ and CS) were given the same volume of sterile physiological solution ( $3 \mu \mathrm{L}$ of $0.9 \% \mathrm{NaCl}$ solution). The euthanasia of Acanthamoeba sp.-infectedmice were at 8,16 , and 24 days post infection (dpi), depending on clinical signs and degree of infection (excitation or limited mobility, emaciation, ataxia, tremors, changes in behavior, tail chasing, ruffled fur, anorexia, hunched posture, dehydration/reducedskinturgor, not eating or drinking, agony). 
The animals were sacrificed with a peritoneal overdose of pentobarbital sodium (Euthasol vet, FATRO, Raamsdonksveer, The Netherlands) $(2 \mathrm{~mL} / \mathrm{kg}$ body weight) and subsequently necropsied. The virulence of the amoebae was determined on the degree of infection. Fragments ( $5 \mathrm{~mm} \times 5 \mathrm{~mm}$ ) of the lungs were inoculated on $\mathrm{NN}$ agar and incubated at $41{ }^{\circ} \mathrm{C}$ to assess the infection intensity level [8]. The plates were monitored daily by microscope for 10 days at low magnification. The animals and their lungs were weighed. The relative lung ratios were calculated as follows: lung weight (g)/body weight in infected animals: lung weight (g)/body weight in controls [61]. Pulmonary samples for histological and biochemical analyses were fixed and/or stored in $4 \%$ buffered formalin solution (Avantor, Gliwice, Poland), in liquid nitrogen and then stored at $-80^{\circ} \mathrm{C}$, respectively.

\subsection{Clinical Evaluation of the Mice}

Infected animals were scored daily for clinical signs, behavior, appetite and mortality. The following elements were analyzed: activity of the mice, feeding, appearance of the fur, hunched position, ataxia and tremors as described in [62]. The points used to assess the clinical status were 0,1 and 2 . The average of three measures was taken, if the average total score was 3 , the mice was classified as severely sick (humanitary end point), if between 4 and 7 the mice were moderately sick, and if the total score was over 8 , the micewere deemed healthy (without symptoms).

\subsection{Western Blotting Analysis of COX-1 and COX-2 Expression}

RIPA buffer ( $\mathrm{pH}$ 7.4) was used for lung sample homogenization using a previously described method [21]. To asses total protein concentrations we used Micro BCA Protein Assay Kits (Thermo Scientific, Rockford, IL, USA). Lung homogenates were subjected to SDS-polyacrylamide gel electrophoresis and examined for protein expression of COX-1 and COX-2. Western blotting analysis of COX-1 and COX-2 expression was performed essentially as previously described by Olszowski et al. [37].

\subsection{Measurements of Prostaglandin $E_{2}$ and Thromboxane $B_{2}$ Concentrations}

The activity of COX-1 and COX-2 enzymes was determined by quantitative measurement of their products: $\mathrm{PGE}_{2}$ and $\mathrm{TXB}_{2}$ extracted from a homogenate of lung samples using Bakerbond columns (Witko Group, Łódź, Poland). The measurements of $\mathrm{PGE}_{2}$ and $\mathrm{TXB}_{2}$ levels were conducted using appropriate immunoenzymatic sets (Prostaglandin E 2 EIA Kit, Cayman, Ann Arbor, MI, USA; Thromboxane $\mathrm{B}_{2}$ EIA Kit, Cayman, Ann Arbor, MI, USA) according to the manufacturer's instructions. The concentrations of $\mathrm{PGE}_{2}$ and $\mathrm{TXB}_{2}$ were expressed in pg per mg protein.

\subsection{Immunohistochemistry of COX-1 and COX-2 Expression}

Paraffin-embedded sections ( $3-5 \mu \mathrm{m})$ of mice lungs were immunostained for the visualization of COX-1 and COX-2 proteins expression. Immunohistochemistry wasperformed using specific primary goat polyclonal antibodies (Santa Cruz Biotechnology, Dallas, TX, USA) against COX-1 and COX-2 in a final 1:100 dilution. Immunohistochemistry of COX-1 and COX-2 expression were performed essentially as previously described [21].

Firstly, the deparaffinized sections were microwave irradiated in citrate buffer ( $\mathrm{pH}$ 6.0) to heat induce epitope retrieval. After slow cooling to room temperature, slides were washed in phosphate-buffered saline (PBS) solution twice for $5 \mathrm{~min}$ and then incubated for $60 \mathrm{~min}$ with primary antibodies. Following this, sections were stained using an avidin-biotin-peroxidase system with diaminobenzidine (DAKO (HRP; Rabbit/Mouse/Goat (DAB+); DakoCytomation, Glostrup, Denmark) as the chromogen, in conformity with the staining procedure instructions included. Sections were washed in distilled $\mathrm{H}_{2} \mathrm{O}$ and counterstained with hematoxylin. For a negative control, specimens were processed in the absence of primary antibodies. Positive staining was defined microscopically (Leica DM5000 B, Hamburg, Germany) by visual identification of brown pigmentation [21]. 


\subsection{Statistical Analysis}

Statistical analysis was carried using Statistica 10 PL software. The arithmetic means (AM), standard deviations of the AM (SD), medians (Med) were calculated for each studied group. The distribution normality was examined using Shapiro-Wilk $W$-test. The nonparametric tests (Kruskal-Wallis and Mann-Whitney $U$ test) were used in the analysis because distributions in most cases deviated from normal. Correlations between the parameters were tested by Spearman rank correlation coefficient $\left(r_{\mathrm{s}}\right)$. The significance level was $p<0.05$.

\section{Conclusions}

Acanthamoeba sp. induced a strong expression of COX-1 and COX-2 proteins in the lungs of immunocompetent mice. These results suggested that similar to COX-2, COX-1 is an important mediator of the pathophysiology in experimental acanthamoebiasis. In this study, we noted that strong expression of COX-1 and COX-2 proteins in the lungs of immunocompetent hosts induced by the parasite, does not correspond to significant differences in the expression the eicosanoids $\mathrm{PGE}_{2}$ and $\mathrm{TXB}_{2}$. Immunosuppression induced by glucocorticoids in Acanthamoeba sp.-infected mice caused a decrease in COX-1 and COX-2 (not at the beginning of infection) in lung tissue. We suggest that the signaling pathways important for Acanthamoeba sp. induction of lung infection might interact with each other and depend on the host immune status. However, the pathogenesis of pulmonary invasion by Acanthamoeba sp. is still poorly understood and documented, and so requires further research.

Acknowledgments: The Pomeranian Medical University in Szczecin provided financial support (WLBiML-431-04/S/14/2017).

Author Contributions: Łanocha-Arendarczyk Natalia and Kosik-Bogacka Danuta conceived and designed the research; Łanocha-Arendarczyk Natalia, Kosik-Bogacka Danuta, Baranowska-Bosiacka Irena and Kot Karolina performed the experiments; Łanocha-Arendarczyk Natalia, Baranowska-Bosiacka Irena, Gutowska Izabela, Kolasa-Wołosiuk Agnieszka, analyzed the data; Łanocha-Arendarczyk Natalia and Kosik-Bogacka Danuta contributed to writing the manuscript; Chlubek Dariusz prepared a final version of manuscript for publication. All authors read and approved the final manuscript.

Conflicts of Interest: The authors declare no conflict of interest.

\section{Abbreviations}

A

AK

$\mathrm{AM}$

AM 22

Med

AML

AS

C

CA

cAMP

COX-1

COX-2

CS

dpi

ERK 1/2 extracellular signal-regulated kinase

PGA prostaglandin

$\mathrm{PGE}_{2} \quad$ prostaglandin $\mathrm{E}_{2}$

GAE granulomatous amebic encephalitis

IK immunocompetent 


$\begin{array}{ll}\text { IL-4 } & \text { interkeukin } 4 \\ \text { IL-13 } & \text { Interleukin 13 } \\ \text { IL- } \beta & \text { interleukin } 1 \text { beta } \\ \text { iNOS } & \text { inducible nitric oxide synthase } \\ \text { IS } & \text { immunosuppressed } \\ \text { JNK } & \text { c-Jun N-terminal kinases } \\ \text { K-W test } & \text { Kruskal-Wallis test } \\ \text { LI } & \text { relative weight ratio of lungs } \\ \text { LPS } & \text { lipopolysaccharide } \\ \text { MPS } & \text { methylprednisolone sodium succinate } \\ \text { MRP } & \text { multidrug resistance protein 4 } \\ \text { NF- } \mathrm{kB} & \text { nuclear transcription factor } \\ \text { NSAIDs } & \text { non-steroidal anti-inflammatory drugs } \\ \text { p38 } & \text { mitogen-activated protein kinase } \\ \mathrm{r}_{\mathrm{S}} & \text { correlation coefficient } \\ \text { SD } & \text { standard deviation } \\ \text { TLR2 } & \text { Toll-like receptor } 2 \\ \text { TLR4 } & \text { Toll-like receptor } 4 \\ \text { TXs } & \text { thromboxanes } \\ \text { TXA } & \text { thromboxane A } \\ \text { TXB } & \text { thromboxane } B_{2}\end{array}$

\section{References}

1. Siddiqui, R.; Khan, N.A. Biology and pathogenesis of Acanthamoeba. Parasites Vectors 2012, 5, 6. [CrossRef] [PubMed]

2. Lanocha, N.; Kosik-Bogacka, D.; Maciejewska, A.; Sawczuk, M.; Wilk, A.; Kuźna-Grygiel, W. The occurrence Acanthamoeba (free living amoeba) in environmental and respiratory samples in Poland. Acta Protozool. 2009, $48,271-279$.

3. Lorenzo-Morales, J.; Khan, N.A.; Walochnik, J. An update on Acanthamoeba keratitis: Diagnosis, pathogenesis and treatment. Parasite 2015, 22, 10. [CrossRef] [PubMed]

4. Park, M.K.; Cho, M.K.; Kang, S.A.; Park, H.K.; Kim, D.H.; Yu, H.S. Acanthamoeba protease activity promotes allergic airway inflammation via protease-activated receptor 2. PLoS ONE 2014, 9, e92726. [CrossRef]

5. Im, K.; Kim, D.S. Acanthamoebiasis in Korea: Two new cases with clinical cases review. Yonsei Med. J. 1998, 39, 478-484. [CrossRef] [PubMed]

6. Vernon, S.E.; Acar, B.C.; Pham, S.M.; Fertel, D. Acanthamoeba infection in lung transplantation: Report of a case and review of the literature. Transpl. Infect. Dis. 2005, 7, 154-157. [CrossRef] [PubMed]

7. Martínez-Girón, R.; Esteban, J.G.; Ribas, A.; Doganci, L. Protozoa in respiratory pathology: A review. Eur. Respir. J. 2008, 32, 1354-1370. [CrossRef] [PubMed]

8. Górnik, K.; Kuźna-Grygiel, W. Histological studies of selected organs of mice experimentally infected with Acanthamoeba spp. Folia Morphol. 2005, 64, 161-167.

9. Lee, I.T.; Yang, C.M. Inflammatory signalings involved in airway and pulmonary diseases. Mediat. Inflamm. 2013, 2013, 791231. [CrossRef] [PubMed]

10. Szymanski, K.V.; Toennies, M.; Becher, A.; Fatykhova, D.; N'Guessan, P.D.; Gutbier, B.; Klauschen, F.; Neuschaefer-Rube, F.; Schneider, P.; Rueckert, J.; et al. Streptococcus pneumoniae-induced regulation of cyclooxygenase-2 in human lung tissue. Eur. Respir. J. 2012, 40, 1458-1467. [CrossRef] [PubMed]

11. Dannhardt, G.; Kiefer, W. Cyclooxygenase inhibitors-current status and future prospects. Eur. J. Med. Chem. 2001, 36, 109-126. [CrossRef]

12. Zarghi, A.; Arfaei, S. Selective COX-2 inhibitors: A review of their structure-activity relationships. Iran. J. Pharm. Res. 2011, 10, 655-683. [PubMed]

13. Hartert, T.V.; Dworski, R.T.; Mellen, B.G.; Oates, J.A.; Murray, J.J.; Sheller, J.R. Prostaglandin E 2 decreases allergen-stimulated release of prostaglandin $\mathrm{D}_{2}$ in airways of subjects with asthma. Am. J. Respir. Crit. Care Med. 2000, 162, 637-640. [CrossRef] [PubMed] 
14. Lundström, S.L.; Levänen, B.; Nording, M.; Klepczynska-Nyström, A.; Sköld, M.; Haeggström, J.Z.; Grunewald, J.; Svartengren, M.; Hammock, B.D.; Larsson, B.M.; et al. Asthmatics exhibit altered oxylipin profiles compared to healthy individuals after subway air exposure. PLoS ONE 2011, 6, e23864. [CrossRef] [PubMed]

15. Horikiri, T.; Hara, H.; Saito, N.; Araya, J.; Takasaka, N.; Utsumi, H.; Yanagisawa, H.; Hashimoto, M.; Yoshii, Y.; Wakui, H.; et al. Increased levels of prostaglandin E-major urinary metabolite (PGE-MUM) in chronic fibrosing interstitial pneumonia. Respir. Med. 2017, 122, 43-50. [CrossRef] [PubMed]

16. Claar, D.; Hartert, T.V.; Peebles, R.S., Jr. The role of prostaglandins in allergic lung inflammation and asthma. Expert Rev. Respir. Med. 2015, 9, 55-72. [CrossRef] [PubMed]

17. Wenzel, S.E.; Westcott, J.Y.; Larsen, G.L. Bronchoalveolar lavage fluid mediator levels 5 minutes after allergen challenge in atopic subjects with asthma: Relationship to the development of late asthmatic responses. J. Allergy Clin. Immunol. 1991, 87, 540-548. [CrossRef]

18. Hasturk, S.; Kemp, B.; Kalapurakal, S.K.; Kurie, J.M.; Hong, W.K.; Lee, J.S. Expression of cyclooxygenase-1 and cyclooxygenase-2 in bronchial epithelium and nonsmall cell lung carcinoma. Cancer 2002, 94, 1023-1031. [CrossRef] [PubMed]

19. Radi, Z.A. Pathophysiology of cyclooxygenase inhibition in animal models. Toxicol. Pathol. 2009, 37, 34-46. [CrossRef] [PubMed]

20. Walenga, R.W.; Kester, M.; Coroneos, E.; Butcher, S.; Dwivedi, R.; Statt, C. Constitutive expression of prostaglandin endoperoxide G/H synthetase (PGHS)-2 but not PGHS-1 in human tracheal epithelial cells in vitro. Prostaglandins 1996, 52, 341-359. [CrossRef]

21. Kosik-Bogacka, D.I.; Baranowska-Bosiacka, I.; Kolasa-Wołosiuk, A.; Lanocha-Arendarczyk, N.; Gutowska, I.; Korbecki, J.; Namięta, H.; Rotter, I. The inflammatory effect of infection with Hymenolepis diminuta via the increased expression and activity of COX-1 and COX-2 in the rat jejunum and colon. Exp. Parasitol. 2016, 169, 69-76. [CrossRef] [PubMed]

22. Asaad, N.Y.; Sadek, G.S. Pulmonary cryptosporidiosis: Role of COX2 and NF-кB. APMIS 2006, 114, 682-689. [CrossRef] [PubMed]

23. Lonardoni, M.V.; Russo, M.; Jancar, S. Essential role of platelet-activating factor in control of Leishmania (Leishmania) amazonensis infection. Infect. Immun. 2000, 68, 6355-6361. [CrossRef] [PubMed]

24. Lejeune, M.; Moreau, F.; Chadee, K. Prostaglandin $\mathrm{E}_{2}$ produced by Entamoeba histolytica signals via $\mathrm{EP}_{4}$ receptor and alters claudin-4 to increase ion permeability of tight junctions. Am. J. Pathol. 2011, 179, 807-818. [CrossRef] [PubMed]

25. Bhattacharjee, A.; Majumder, S.; Das, S.; Ghosh, S.; Biswas, S.; Majumdar, S. Leishmania donovani-induced prostaglandin $\mathrm{E}_{2}$ generation is critically dependent on host toll-like receptor 2-cytosolic phospholipase A2 signaling. Infect. Immun. 2016, 84, 2963-2973. [CrossRef] [PubMed]

26. Michelin, M.A.; Silva, J.S.; Cunha, F.Q. Inducible cyclooxygenase released prostaglandin mediates immunosuppression in acute phase of experimental Trypanosoma cruzi infection. Exp. Parasitol. 2005, 111, 71-79. [CrossRef] [PubMed]

27. Abdalla, G.K.; Faria, G.E.; Silva, K.T.; Castro, E.C.; Reis, M.A.; Michelin, M.A. Trypanosoma cruzi: The role of $\mathrm{PGE}_{2}$ in immune response during the acute phase of experimental infection. Exp. Parasitol. 2008, 118, 514-521. [CrossRef] [PubMed]

28. Malvezi, A.D.; Panis, C.; da Silva, R.V.; de Freitas, R.C.; Lovo-Martins, M.I.; Tatakihara, V.L.; Zanluqui, N.G.; Neto, E.C.; Goldenberg, S.; Bordignon, J.; et al. Inhibition of cyclooxygenase-1 and cyclooxygenase-2 impairs Trypanosoma cruzi entry into cardiac cells and promotes differential modulation of the inflammatory response. Antimicrob. Agents Chemother. 2014, 58, 6157-6164. [CrossRef] [PubMed]

29. Anyona, S.B.; Kempaiah, P.; Davenport, G.C.; Vulule, J.M.; Hittner, J.B.; Ong'echa, J.M.; Perkins, D.J. Suppressed circulating bicyclo-PGE 2 levels and leukocyte COX-2 transcripts in children co-infected with $P$. falciparum malaria and HIV-1 or bacteremia. Biochem. Biophys. Res. Commun. 2013, 436, 585-590. [CrossRef] [PubMed]

30. Hadas, E.; Mazur, T. Biosynthesis of prostaglandins in pathogenic and nonpathogenic strains of Acanthamoeba spp. Parasitol. Res. 1997, 83, 296-299. [CrossRef] [PubMed]

31. Eida, A.M. Prostanoids and parasitic diseases. Parasitol. United J. 2015, 8, 38-51. [CrossRef] 
32. Radi, Z.A.; Meyerholz, D.K.; Ackermann, M.R. Pulmonary cyclooxygenase-1 (COX-1) and COX-2 cellular expression and distribution after respiratory syncytial virus and parainfluenza virus infection. Viral Immunol. 2010, 23, 43-48. [CrossRef] [PubMed]

33. Lacroix, S.; Mancassola, R.; Naciri, M.; Laurent, F. Cryptosporidium parvum-specific mucosal immune response in C57BL/ 6 neonatal and $\gamma$ interferon-deficient mice: Role of tumor necrosis factor alpha in protection. Infect. Immun. 2001, 69, 1635-1642. [CrossRef] [PubMed]

34. Basir, R.; Rahiman, S.F.; Hasballah, K.; Chong, W.; Talib, H.; Yam, M.; Jabbarzare, M.; Tie, T.; Othman, F.; Moklas, M.; et al. Plasmodium berghei ANKA infection in ICR mice as a model of cerebral malaria. Iran. J. Parasitol. 2012, 7, 62-74. [PubMed]

35. Abdel-Hafeez, E.H.; Ahmed, A.K.; Abdellatif, M.Z.; Kamal, A.M.; Toni, M.D. The efficacy of pomegranate (Punicagranatum) peel extract on experimentally infected rats with Blastocystis spp. J. Infect. Dis. Prev. Med. 2016, 4, 131. [CrossRef]

36. Wilson, B.D.; Mondloch, V.M.; Katzenstein, A.L.; Moore, V.L. Hypersensitivity pneumonitis in rabbits. Modulation of pulmonary inflammation by long-term aerosol challenge with antigen. J. Allergy Clin. Immunol. 1984, 74, 180-184. [CrossRef]

37. Olszowski, T.; Gutowska, I.; Baranowska-Bosiacka, I.; Piotrowska, K.; Korbecki, J.; Kurzawski, M.; Chlubek, D. The Effect of cadmium on COX-1 and COX-2 gene, protein expression, and enzymatic activity in THP-1 macrophages. Biol. Trace Elem. Res. 2015, 165, 135-144. [CrossRef] [PubMed]

38. Carey, M.A.; Germolec, D.R.; Langenbach, R.; Zeldin, D.C. Cyclooxygenase enzymes in allergic inflammation and asthma. Prostaglandins Leukot. Essent. Fatty Acids 2003, 69, 157-162. [CrossRef]

39. Kirkby, N.S.; Zaiss, A.K.; Wright, W.R.; Jiao, J.; Chan, M.V.; Warner, T.D.; Herschman, H.R.; Mitchell, J.A. Differential COX-2 induction by viral and bacterial PAMPs: Consequences for cytokine and interferon responses and implications for anti-viral COX-2 directed therapies. Biochem. Biophys. Res. Commun. 2013, 438, 249-256. [CrossRef] [PubMed]

40. Radi, Z.A.; Ackermann, M.R. Ontogeny of pulmonary cyclooxygenase-1 (COX-1) and -2 (COX-2). Pathophysiology 2011, 18, 215-219. [CrossRef] [PubMed]

41. Hoesel, B.; Schmid, J.A. The complexity of NF-кB signaling in inflammation and cancer. Mol. Cancer 2013, 212, 86. [CrossRef] [PubMed]

42. Korbecki, J.; Baranowska-Bosiacka, I.; Gutowska, I.; Chlubek, D. Cyclooxygenase pathways. Acta Biochim. Pol. 2014, 61, 639-649.

43. Fukata, M.; Chen, A.; Klepper, A.; Krishnareddy, S.; Vamadevan, A.S.; Thomas, L.S.; Xu, R.; Inoue, H.; Arditi, M.; Dannenberg, A.J.; et al. Cox-2 is regulated by Toll-like receptor-4 (TLR4) signaling: Role in proliferation and apoptosis in the intestine. Gastroenterology 2006, 131, 862-877. [CrossRef] [PubMed]

44. Hernandez, Y.; Sotolongo, J.; Breglio, K.; Conduah, D.; Chen, A.; Xu, R.; Hsu, D.; Ungaro, R.; Hayes, L.A.; Pastorini, C.; et al. The role of prostaglandin $\mathrm{E}_{2}\left(\mathrm{PGE}_{2}\right)$ in toll-like receptor 4 (TLR4)-mediated colitis-associated neoplasia. BMC Gastroenterol. 2010, 10, 82. [CrossRef] [PubMed]

45. Derda, M.; Wojtkowiak-Giera, A.; Kolasa-Wołosiuk, A.; Kosik-Bogacka, D.; Hadaś, E.; Jagodziński, P.P.; Wandurska-Nowak, E. Acanthamoeba infection in lungs of mice expressed by toll-like receptors (TLR2 and TLR4). Exp. Parasitol. 2016, 165, 30-34. [CrossRef] [PubMed]

46. Peres-Buzalaf, C.; de Paula, L.; Frantz, F.G.; Soares, E.M.; Medeiros, A.I.; Peters-Golden, M.; Silva, C.L.; Faccioli, L.H. Control of experimental pulmonary tuberculosis depends more on immunostimulatory leukotrienes than on the absence of immunosuppressive prostaglandins. Prostaglandins Leukot. Essent. Fatty Acids 2011, 85, 75-81. [CrossRef] [PubMed]

47. Chen, M.; Divangahi, M.; Gan, H.; Shin, D.S.; Hong, S.; Lee, D.M.; Serhan, C.N.; Behar, S.M.; Remold, H.G. Lipid mediators in innate immunity against tuberculosis: Opposing roles of $\mathrm{PGE}_{2}$ and LXA4 in the induction of macrophage death. J. Exp. Med. 2008, 205, 2791-2801. [CrossRef] [PubMed]

48. Leonard, B.E. The immune system, depression and the action of antidepressants. Program Neuro Psychopharmcol. Biol. Psychiatry 2001, 25, 767-780. [CrossRef]

49. Agard, M.; Asakrah, S.; Morici, L.A. PGE 2 suppression of innate immunity during mucosal bacterial infection. Front. Cell. Infect. Microbiol. 2013, 3, 45. [CrossRef] [PubMed]

50. Vancheri, C.; Mastruzzo, C.; Sortino, M.A.; Crimi, N. The lung as a privileged site for the beneficial actions of $\mathrm{PGE}_{2}$. Trends Immunol. 2004, 25, 40-46. [CrossRef] [PubMed] 
51. Ricciotti, E.; FitzGerald, G.A. Prostaglandins and inflammation. Arterioscler. Thromb. Vasc. Biol. 2011, 31, 986-1000. [CrossRef] [PubMed]

52. Yang, N.; Zhang, W.; Shi, X.M. Glucocorticoid-induced leucine zipper (GILZ) mediates glucocorticoid action and inhibits inflammatory cytokine-induced COX-2 expression. J. Cell. Biochem. 2008, 103, 1760-1771. [CrossRef] [PubMed]

53. Hideko Tatakihara, V.L.; Cecchini, R.; Borges, C.L.; Malvezi, A.D.; Graça-de Souza, V.K.; Yamada-Ogatta, S.F.; Rizzo, L.V.; Pinge-Filho, P. Effects of cyclooxygenase inhibitors on parasite burden, anemia and oxidative stress in murine Trypanosoma cruzi infection. FEMS Immunol. Med. Microbiol. 2008, 52, 47-58. [CrossRef] [PubMed]

54. Liu, S.F.; Newton, R.; Evans, T.W.; Barnes, P.J. Differential regulation of cyclo-oxygenase-1 and cyclo-oxygenase-2 gene expression by lipopolysaccharide treatment in vivo in the rat. Clin. Sci. 1996, 90, 301-306. [CrossRef] [PubMed]

55. Font-Nieves, M.; Sans-Fons, M.G.; Gorina, R.; Bonfill-Teixidor, E.; Salas-Pérdomo, A.; Márquez-Kisinousky, L.; Santalucia, T.; Planas, A.M. Induction of COX-2 enzyme and down-regulation of COX-1 expression by lipopolysaccharide (LPS) control prostaglandin $\mathrm{E}_{2}$ production in astrocytes. J. Biol. Chem. 2012, 287, 6454-6468. [CrossRef] [PubMed]

56. Akundi, R.S.; Candelario-Jalil, E.; Hess, S.; Hüll, M.; Lieb, K.; Gebicke-Haerter, P.J.; Fiebich, B.L. Signal transduction pathways regulating cyclooxygenase-2 in lipopolysaccharide-activated primary rat microglia. Glia 2005, 51, 199-208. [CrossRef] [PubMed]

57. Chen, Q.; Luo, Y.; Kuang, S.; Yang, Y.; Tian, X.; Ma, J.; Mai, S.; Xue, L.; Yang, J. Cyclooxygenase-2 Signalling Pathway in the Cortex is Involved in thePathophysiological Mechanisms in the Rat Model of Depression. Sci. Rep. 2017, 7, 488. [CrossRef] [PubMed]

58. Sumimoto, S.; Muramatsu, R.; Yamashita, T. Thromboxane $\mathrm{A}_{2}$ stimulates neurite outgrowth in cerebral cortical neurons via mitogen activated protein kinasesignaling. Brain Res. 2015, 1594, 46-51. [CrossRef] [PubMed]

59. Culbertson, C.G.; Ensminger, P.W.; Overton, W.M. The isolation of additional strains FF pathogenic Hartmanella sp. (Acanthamoeba): Proposed culture method for application to biological material. Am. J. Clin. Pathol. 1965, 43, 383-387. [PubMed]

60. Markowitz, S.M.; Sobieski, T.; Martinez, A.J.; Duma, R.J. Experimental Acanthamoeba infections in mice pretreated with methylprednisolone or tetracycline. Am. J. Pathol. 1978, 92, 733-744. [PubMed]

61. Pilarczyk, B.; Doligalska, M.J.; Donskow-Schmelter, K.; Balicka-Ramisz, A.; Ramisz, A. Selenium supplementation enhances the protective response to Toxocara canis larvae in mice. Parasite Immunol. 2008, 30, 394-402. [CrossRef] [PubMed]

62. Özkaya, H.; Akcan, A.B.; Aydemir, G.; Aydinöz, S.; Razia, Y.; Gammon, S.T.; McKinney, J. Salmonella typhimurium infections in BALB/c mice: A comparison of tissue bioluminescence, tissue cultures and mice clinical scores. New Microbiol. 2012, 35, 53-59. [PubMed]

(C) 2018 by the authors. Licensee MDPI, Basel, Switzerland. This article is an open access article distributed under the terms and conditions of the Creative Commons Attribution (CC BY) license (http:// creativecommons.org/licenses/by/4.0/). 